\title{
PENGARUH MODEL PEMBELAJARAN WORD SQUARE BERBANTUAN MEDIA GAMBAR TERHADAP HASIL BELAJAR IPS
}

\author{
Kt. Novi Ariawati ${ }^{1}$, A. A. Gede Agung $^{2}$, I Km. Sudarma ${ }^{3}$ \\ ${ }^{1}$ Jurusan PGSD, ${ }^{2,3}$ Jurusan TP, FIP \\ Universitas Pendidikan Ganesha \\ Singaraja, Indonesia \\ email : ariawatinovi@gmail.com ${ }^{1}$, agungtps2056@yahoo.co.id ${ }^{2}$, \\ sudarmadede@gmail.com ${ }^{3}$
}

\begin{abstract}
Abstrak
Permasalahan rendahnya hasil belajar IPS yang ditemukan pada siswa kelas V di Gugus II Kecamatan Kubutambahan menjadi masalah utama dilakukannya penelitian ini. Rendahnya hasil belajar IPS diduga karena guru cenderung menggunakan metode ceramah yang berpusat pada guru dan pembelajaran jarang menggunakan media pembelajaran. Oleh karena itu, penelitian ini dilakukan dengan tujuan untuk mengetahui pengaruh yang signifikan model pembelajaran Word Square berbantuan media gambar terhadap hasil belajar IPS siswa kelas V di Gugus II Kecamatan Kubutambahan tahun pelajaran 2017/2018. Populasi penelitian ini adalah seluruh siswa kelas V di Gugus II Kecamatan Kubutambahan yang menggunakan KTSP yang terdiri atas 6 sekolah dengan jumlah siswa keseluruhan, yaitu 187 siswa. Sampel penelitian adalah siswa kelas V SD Negeri 4 Kubutambahan dengan jumlah 26 siswa dan SD Negeri 7 Kubutambahan dengan jumlah 25 siswa. Data hasil belajar IPS dikumpulkan menggunakan metode tes, dengan instrumen tes objektif bentuk pilihan ganda. Data hasil penelitian tersebut dianalisis dengan teknik analisis statistik deskriptif dan analisis statistik inferensial (uji-t). Hasil penelitian menunjukan bahwa: (1) rata-rata hasil belajar siswa kelompok eksperimen sebesar 22,64 berada pada kategori sangat tinggi, (2) rata-rata hasil belajar siswa kelompok kontrol sebesar 18,92 berada pada kategori tinggi, (3) hasil uji hipotesis dengan menggunakan uji-t, diperoleh $t_{\text {hitung }}$ lebih besar daripada $t_{\text {tabel }}(3,683>1,667)$. Berdasarkan hasil analisis data tersebut dapat disimpulkan bahwa terdapat pengaruh yang signifikan model pembelajaran Word Square berbantuan media gambar terhadap hasil belajar IPS siswa kelas V di Gugus II Kecamatan Kubutambahan tahun pelajaran 2017/2018.
\end{abstract}

Kata kunci: Gambar, Hasil Belajar IPS, Word Square

\begin{abstract}
The problems of low social science learning result found in fifth grade students in cluster II Kubutambahan sub district was the major issue in this research. The low social science learning result were suspected because teacher tend to using teacher centerd lecture methods and learning rarely using instructional media. Therefore, this study was conducted with the aimed to determine the significant effect of learning model Word Square using picture to social science learning result at fifth grade student in cluster II Kubutambahan district in the academic year of 2017/2018. The population of this study were 187 of fifth grade students at 6 elementary school which used KTSP in cluster II Kubutambahan district. The sampel of this study was 26 fifth grade students of SD Negeri 4 Kubutambahan and 25 fifth grade students of SD Negeri 7 Kubutambahan. Students social science learning results data was collected by using test method, with instrument multiple choice objective test. The result data of research were analyzed by descriptive statistical analysis technique and inferential statistical analysis (t-test). The result of this study showed: (1) the average of the students result in experimental group is 22,64, categorized as very high, (2) the average of the students result in control group is 18,92 categorized as high, (3) the result hypothesis using $t$-test, obtained $t_{\text {arithmetic }}$ bigger than $t_{\text {able }}(3,683>1,667)$. Based on result analysis data, the research can be conclude there is any significants effect of leraning model Word Square using picture to social science learning result at fifth grade student in cluster II Kubutambahan district in the academic year of $2017 / 2018$.
\end{abstract}

Keywords: Picture, Social Science Learning Result, Word Square 


\section{Pendahuluan}

Saat ini paradigma pembelajaran di Indonesia sudah mengalami perubahan seiring dengan kemajuan zaman. Perubahan paradigma pembelajaran yang semula berpusat pada guru (teacher centred) bergeser menjadi pembelajaran yang berpusat pada siswa (student centred). Paradigma baru tersebut berkaitan dengan bagaimana siswa dapat belajar dengan baik bukan lagi bagaimana guru dapat menyampaikan materi keseluruhan dengan baik. Paradigma baru ini, memandang siswa yang memegang peranan utama dalam proses pembelajaran. Dalam proses pembelajaran siswa dituntut terlibat secara aktif untuk membangun pengetahuannya sendiri. Sehingga, siswa mampu memperoleh pemahaman yang mendalam, dan pada akhirnya dapat meningkatkan mutu kualitas siswa dan mutu kualitas pembelajaran. Terkait dengan perubahan paradigma ini menuntut guru untuk dapat merancang pembelajaran yang berbasis aktivitas. Pembelajaran berbasis aktivitas dengan karakteristik, yaitu interaktif, menyenangkan, menantang, memotivasi, kontekstual dan kolaboratif, menarik minat siswa, membangkitkan semangat belajar, dan meningkatkan keaktifan siswa (Permendikbud Nomor 103 Tahun 2014 pasal 2 ayat 1). Selain itu, pembelajaran juga harus disertai dengan menggunakan media pembelajaran karena siswa SD masih berada pada tahap operasional konkret. Menurut Rusman (2015) tahap operasional konkret adalah tahap perkembangan kognitif anak dimulai dari usia 6 sampai 12 tahun. Pada tahap ini anak berpikir terbatas pada objek yang diamati secara langsung. Dengan demikian, guru harus menerapkan model-model pembelajaran inovatif yang berbasis aktivitas dan memperhatikan tahap perkembangan siswa. Sehingga dapat membantu meningkatkan hasil belajar siswa. Pembelajaran demikian, harus terjadi pada semua mata pelajaran di sekolah, termasuk mata pelajaran IPS.

IPS adalah ilmu pengetahuan yang memadukan sejumlah konsep pilihan dari berbagai cabang ilmu sosial, seperti sosiologi, sejarah, geografi, ekonomi, politik, hukum, dan budaya (Trianto, 2014). Lebih lanjut menurut Lestari (2013) IPS merupakan ilmu pengetahuan yang digali dari kehidupan sehari-hari di masyarakat. Masyarakat dijadikan sumber dan objek kajian materi pembelajaran IPS. Susanto (2016:145) "tujuan pembelajaran IPS ialah untuk mengembangkan potensi peserta didik agar peka terhadap masalah sosial yang terjadi di masyarakat dan dapat mengatasi setiap masalah yang terjadi sehari-hari baik yang menimpa dirinya maupun yang menimpa masyarakat". Pembelajaran IPS tidak hanya berupa hafalan materi tetapi meliputi aspek pengetahuan, keterampilan, dan nilai. Oleh karena itu, pembelajaran IPS di SD harus dirancang dengan menyenangkan, menarik minat siswa, meningkatkan keaktifan siswa, menciptakan interaksi multi arah, dan memperhatikan tahap perkembangan siswa.

Namun fakta yang ditemukan di lapangan, pembelajaran IPS masih belum sesuai harapan. Berdasarkan hasil wawancara yang telah dilakukan dengan guru IPS kelas $V$ di Gugus II Kecamatan Kubutambahan yang menggunkanan KTSP pada tanggal 8 dan 9 Desember 2017, didapat hasil wawancara dari 6 (enam) orang guru IPS di kelas V sebagai berikut. Pertama, 4 orang guru mengungkap bahwa, pembelajaran yang dilakukan masih bersifat konvensional dengan metode ceramah, tanya jawab, dan penugasan, dan 2 orang guru mengungkap bahwa, pembelajaran IPS kadang dilakukan dengan diskusi kelompok. Kedua, 6 orang guru mengungkap bahwa kebanyakan siswa merasa bosan dan tidak bersemangat dalam mengikuti proses pembelajaran IPS. Ketiga, 6 orang guru mengungkap bahwa, pembelajaran yang dilakukan jarang menggunakan media pembelajaran. Keempat, hasil belajar yang diperoleh siswa masih rendah.

Selain, wawancara dilakukan pencatatan dokumen. Berdasarkan hasil pencatatan dokumen pada tanggal 8 dan 9 Desember 2017, diketahui bahwa nilai KKM yang ditetapkan untuk mata pelajaran IPS kelas V di Gugus II Kecamatan Kubutambahan berkisar dari 69-75, sedangkan hasil belajar IPS yang diperoleh siswa masih ada yang di bawah KKM. Hal tersebut dapat tercermin dari nilai UAS tahun pelajaran 2017/2018. Nilai rata-rata IPS dapat dilihat pada Tabel 1. 
Tabel 1. Nilai Rata-rata UAS Mata Pelajaran IPS Kelas V Semester Ganjil

\begin{tabular}{|c|c|c|c|c|c|c|c|}
\hline \multirow[b]{2}{*}{ Sekolah } & \multirow[b]{2}{*}{$\begin{array}{c}\text { Jumlah } \\
\text { Siswa }\end{array}$} & \multirow[b]{2}{*}{ KKM } & \multirow[b]{2}{*}{$\begin{array}{c}\text { Rata- } \\
\text { rata }\end{array}$} & \multicolumn{2}{|c|}{ Tuntas } & \multicolumn{2}{|c|}{ Tidak Tuntas } \\
\hline & & & & $\begin{array}{c}\text { Jumlah } \\
\text { Siswa }\end{array}$ & $\%$ & $\begin{array}{c}\text { Jumlah } \\
\text { Siswa }\end{array}$ & $\%$ \\
\hline SD Negeri 2 Kubutambahan & 30 & 75 & 72 & 13 & 43,3 & 17 & 56,7 \\
\hline SD Negeri 3 Kubutambahan & 38 & 75 & 70,8 & 13 & 34,2 & 25 & 65,8 \\
\hline SD Negeri 4 Kubutambahan & 26 & 75 & 72 & 10 & 38,5 & 16 & 61,5 \\
\hline SD Negeri 5 Kubutambahan & 40 & 75 & 71,9 & 19 & 47,5 & 21 & 52,5 \\
\hline SD Negeri 6 Kubutambahan & 28 & 72 & 71,6 & 13 & 46,4 & 15 & 53,6 \\
\hline SD Negeri 7 Kubutambahan & 25 & 69 & 67,7 & 8 & 32 & 17 & 68 \\
\hline
\end{tabular}

(Sumber: Guru Kelas V di Gugus II Kecamatan Kubutambahan, 2017)

Hasil wawancara dan pencatatan dokumen diperkuat dengan hasil observasi pada tanggal 3, 4, 8, dan 9 Januari 2018. Hasil observasi yang diperoleh sebagai berikut. Pertama, proses pembelajaran di kelas didominasi oleh guru. Kedua, suasana pembelajaran kurang kondusif. Ketiga, siswa terlihat bosan dan mengantuk.

Permasalahan tersebut perlu dicarikan solusi agar hasil belajar siswa bisa optimal. Salah satu solusi yang dapat dilakukan yaitu dengan menerapkan model pembelajaran yang inovatif yang dapat menciptakan suasana pembelajaran menyenangkan, menarik minat siswa, meningkatkan keaktifan siswa. Salah satu model pembelajaran yang dapat digunakan yaitu model pembelajaran Word Square berbantuan media gambar.

Menurut Kurniasih dan Berlin (2015:97) "model pembelajaran Word Square adalah model pengembangan dari metode ceramah yang diperkaya dan berorientasi kepada keaktifan siswa dalam pembelajaran". Model pembelajaran ini seperti mengisi teka teki silang, tetapi model ini sudah memiliki jawaban. Namun, pada kotak tersebut ditambahkan kotak lain dengan sembarang huruf pengecoh. Pembelajaran dengan menggunakan model pembelajaran Word Square dapat meningkatkan ketelitian siswa

Model pembelajaran Word Square memiliki beberapa langkah-langkah pembelajaran. Menurut Aqib (2016:31-32) "langkah-langkah model pembelajaran ini adalah sebagai berikut. (a) Sampaikan materi sesuai TPK. (b) Bagikan lembar kegiatan sesuai dengan contoh. (c) Siswa disuruh menjawab soal kemudian mengarsir huruf dalam kotak sesuai jawaban. (d) Berikan poin setiap jawaban dalam kotak".

Pembelajaran yang dilakukan dengan model pembelajaran Word Square dibantu dengan menggunakan media gambar. Media gambar merupakan salah satu media pembelajaran yang sering digunakan oleh guru. Penggunaan media gambar dalam proses pembelajaran dapat menarik minat dan perhatian siswa dalam mengikuti pembelajaran. Menurut Sadiman, dkk (2005) kelebihan media gambar, yaitu sifatnya konkret dan dapat mengatasi batasan ruang dan waktu. Artinya pembelajaran dengan menggunakan media gambar memberikan gambaran nyata tentang materi yang dipelajari dan materi tersebut dapat dibawa ke kelas melalui media gambar tanpa guru harus mengajak siswa ke tempat tersebut.

Sehubungan dengan hal tersebut, maka perlu dilakukan penelitian dengan judul "Pengaruh Model Pembelajaran Word Square Berbantuan Media Gambar terhadap Hasil Belajar IPS Siswa Kelas V di Gugus II Kecamatan Kubutambahan Tahun Pelajaran 2017/2018".

Tujuan dari penelitian ini, yaitu untuk mengetahui pengaruh yang signifikan model pembelajaran Word Square berbantuan media gambar terhadap hasil belajar IPS siswa kelas V di Gugus II Kecamatan Kubutambahan Tahun Pelajaran 2017/2018.

\section{Metode}

Tempat pelaksanaan penelitian ini di SD Gugus II Kecamatan Kubutambahan pada rentang waktu semester genap tahun pelajaran 2017/2018. Penelitian ini adalah penelitian 
eksperimen yang tergolong penelitian eksperimen semu (quasi experiment) karena tidak semua variabel lain yang muncul dapat diatur dan dikontrol secara ketat. Penelitian ini menggunakan rancangan non-equivalent post test only control group design yang tampak pada Gambar 1.

\begin{tabular}{|lll|}
\hline $\mathrm{E}:$ & $\mathrm{X}$ & $\mathrm{O}_{1}$ \\
\hline $\mathrm{K}:$ & - & $\mathrm{O}_{2}$ \\
\hline
\end{tabular}

\section{Gambar 1. Rancangan Non-Equivalent Post Test Only Control Group Design}

$\begin{array}{cll}\text { Keterangan: } & \\ \mathrm{E} & = & \text { kelompok eksperimen } \\ \mathrm{K} & = & \text { kelompok kontrol } \\ \mathrm{X} & = & \text { perlakuan dengan menggunakan model pembelajaran Word Square } \\ & & \text { berbantuan media gambar } \\ - & = & \text { tidak diberikan perlakuan dengan menggunakan model pembelajaran Word } \\ & & \text { Square berbantuan media gambar } \\ \mathrm{O}_{1} & = & \text { post test terhadap kelompok eksperimen } \\ \mathrm{O}_{2} & = & \text { post test terhadap kelompok kontrol }\end{array}$

(Sumber: dimodifikasi dari Gall, et al dalam Agung, 2014)

Pelaksanaan penelitian ini terdiri atas tiga tahap, yaitu tahap persiapan, tahap pelaksanaan, dan tahap akhir. Tahap persipaan meliputi merancang perangkat pembelajaran dan istrumen penelitian, mengkonsultasikan perangkat pembelajaran dan istrumen penelitian dengan dosen pembimbing, mengujicoba instrumen, menganalisis hasil uji coba, dan merevisi instrumen penelitian. Pada tahap pelaksanan, pertemuan dilakukan sebanyak 10 kali, dengan 9 kali pertemuan pemberian perlakuan dan 1 kali pemberian post test. Kelompok eksperimen diberikan perlakuan dengan menggunakan model pembelajaran Word Square berbantuan media gambar sedangkan kelompok kontrol tidak diberikan perlakuan dengan menggunakan model pembelajaran Word Square berbantuan media gambar. Pada tahap akhir, melakukan analisis data dan menguji hipotesis serta menyusun laporan penelitian sesuai hasil analisis data.

Populasi penelitian ini adalah siswa kelas V di Gugus II Kecamatan Kubutambahan yang menggunakan KTSP yang terdiri atas 6 sekolah dengan jumlah seluruh siswa, yaitu 187 siswa. Sebelum penentuan sampel penelitian, perlu diketahui bahwa populasi tersebut memiliki kemampuan setara, maka perlu dilakukan uji kesetaraan. Uji kesetaraan dilakukan dengan menganalisis hasil UAS mata pelajaran IPS siswa kelas $V$ semester ganjil tahun pelajaran 2017/2018 dengan menggunakan rumus analisis varians satu jalur (Anava A). Berdasarkan hasil uji kesetaraan, diperoleh $F_{\text {hitung }}$ lebih kecil daripada $F_{\text {tabel }}(1,85<2,26)$, maka populasi tersebut setara. Setelah diketahui populasi tersebut setara, baru menentukan sampel penelitian. Pengambilan sampel penelitian menggunakan teknik sampling acak (random sampling). Pengambilan sampel dengan teknik random sampling pada penelitian ini dilakukan dengan undian. Berdasarkan hasil undian, diperoleh sampel, yaitu SD Negeri 7 Kubutambahan sebagai kelompok eksperimen dengan jumlah 25 siswa dan SD Negeri 4 Kubutambahan sebagai kelompok kontrol dengan jumlah 26 siswa.

Data yang dikumpulkan dalam penelitian ini adalah data hasil belajar IPS siswa kelas V. Untuk mengumpulkan data hasil belajar IPS digunakan metode tes. Instrumen yang digunakan adalah tes objektif bentuk pilihan ganda dengan satu jawaban benar. Setiap soal disertai dengan empat alternatif jawaban yang dapat dipilih oleh siswa (a, b, c, dan d). Setiap butir soal diberikan skor 1 apabila siswa dapat menjawab dengan benar (jawaban dicocokan dengan kunci jawaban) dan skor 0 untuk siswa yang menjawab salah.

Setelah instrumen selesai disusun kemudian diujicobakan di lapangan untuk mengetahui tingkat validitas, reliabilitas, tingkat kesukaran, dan daya beda butir soal. Sebelum uji lapangan, 
dilakukan uji validitas isi oleh pakar di bidang IPS. Berdasarkan hasil uji pakar, diketahui instrumen penelitian tes hasil belajar memiliki kategori sangat tinggi. Selanjutnya, instrumen yang telah mendapat pertimbangan pakar, diujicobakan untuk mendapatkan gambaran secara empirik tentang kelayakan instrumen tersebut dipergunakan sebagai instrumen penelitian. Tes yang diujicobakan berjumlah 40 butir soal yang diberikan kepada 60 testee. Hasil analisis menunjukkan 33 butir soal valid dengan reliabilitas 0,79 . Ini berarti tes yang ujicobakan memiliki reliabilitas tinggi. Hasil tingkat kesukaran, diperoleh 13 butir soal tergolong mudah, 24 butir soal tergolong sedang, dan 3 butir soal tergolong sukar, sedangkan kesukaran perangkat tes adalah 0,55 dengan kriteria sedang. Hasil daya beda, diperoleh 8 butir soal tergolong kurang baik, 28 butir soal tergolong cukup baik, dan 3 butir soal tergolong baik, sedangkan daya beda perangkat tes adalah 0,24, dengan kriteria cukup baik. Berdasarkan hasil pengujian instrumen, maka diperoleh 30 butir soal yang digunakan untuk tes akhir (post test).

Analisis yang digunakan dalam penelitian ini adalah analisis statistik deskriptif dan analisis statistik inferensial. Pada analisis statistik deskriptif, data dianalisis untuk menghitung mean, median, modus, standar deviasi, dan varians. Pada analisis statistik inferensial meliputi uji normalitas dan uji homogenitas varians. Uji normalitas menggunakan Chi-Kuadrat $\left(x^{2}\right)$, dan uji homogenitas varians menggunakan uji-F. Teknik untuk menguji hipotesis penelitian digunakan analisis statistik parametis dengan uji-t sampel tidak berkorelasi dengan rumus polled varians.

\section{Hasil Dan Pembahasan}

Data dalam penelitian ini adalah skor hasil belajar IPS siswa yang diperoleh setelah diberikan perlakuan dengan menggunakan model pembelajaran Word Square berbantuan media gambar pada kelompok eksperimen dan perlakuan yang tidak menggunakan model pembelajaran Word Square berbantuan media gambar pada kelompok kontrol.

Adapun analisis data statistik deskriptif disajikan pada Tabel 2.

Tabel 2. Deskripsi Data Hasil Belajar IPS Kelompok Eksperimen dan Kelompok Kontrol

\begin{tabular}{lcc}
\hline \multicolumn{1}{c}{ Statistik Deskriptif } & Kelompok Eksperimen & Kelompok Kontrol \\
\hline Mean & 22,64 & 18,92 \\
Median & 23 & 18,51 \\
Modus & 23,24 & 17,82 \\
Standar Deviasi & 3,33 & 3,87 \\
Varians & 11,09 & 14,98 \\
\hline
\end{tabular}

Data hasil belajar IPS kelompok eksperimen tersebut kemudian disajikan ke dalam kurva poligon yang tampak pada Gambar 2.

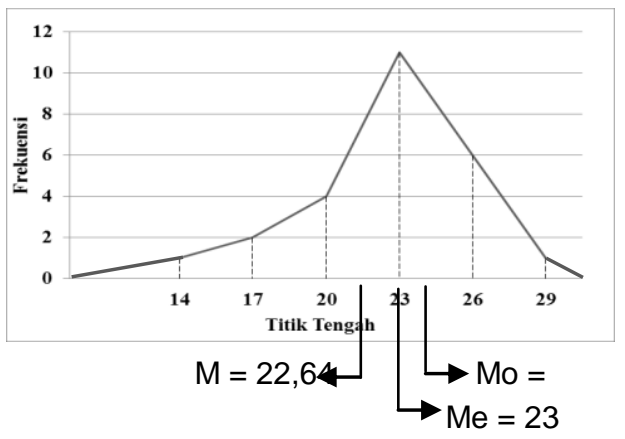

Gambar 2. Kurva Poligon Data Hasil Belajar IPS Kelompok Eksperimen 
Gambar tersebut menunjukkan bahwa modus lebih besar daripada median dan median lebih besar daripada mean $(23,24>23>22,64)$, sehingga kurva yang terbentuk adalah kurva juling negatif yang berarti sebagian besar skor cenderung tinggi. Kurva juling negatif tersebut adalah kurva yang miring ke kanan atau ekor kurva lebih panjang ke kiri.

Untuk mengetahui tinggi rendahnya hasil belajar IPS siswa, skor rata-rata hasil belajar dikonversikan dengan menggunakan kriteria rata-rata ideal $\left(\mathrm{M}_{\mathrm{i}}\right)$ dan standar deviasi ideal $\left(\mathrm{SD}_{\mathrm{i}}\right)$ pada skala lima. Berdasarkan hasil konversi, diketahui skor rata-rata hasil belajar IPS siswa kelompok eksperimen adalah 22,64 berada pada kategori sangat tinggi.

Data hasil belajar IPS kelompok kontrol disajikan ke dalam kurva poligon seperti tampak pada Gambar 3.

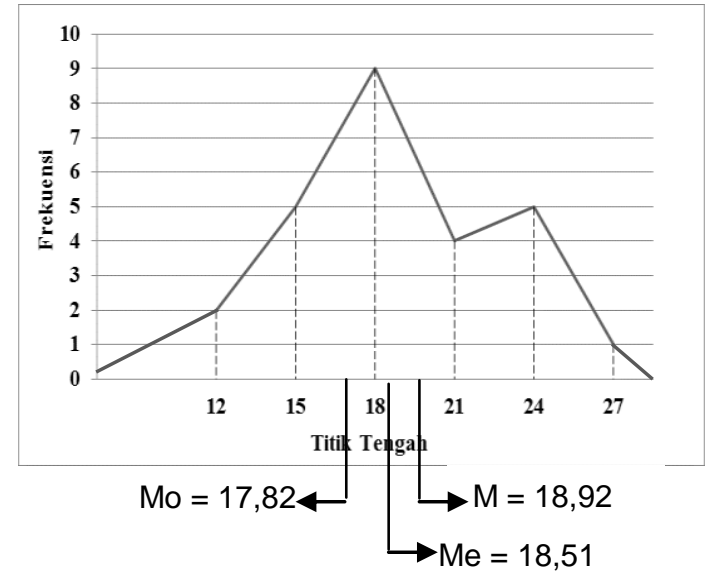

\section{Gambar 3. Kurva Poligon Data Hasil Belajar IPS Kelompok Kontrol}

Gambar tersebut menunjukkan bahwa modus lebih kecil daripada median dan median lebih kecil daripada mean $(17,82<18,51<18,92)$, sehingga kurva yang terbentuk adalah kurva juling positif yang berarti sebagian besar skor cenderung rendah. Kurva juling positif tersebut adalah kurva yang miring ke kiri atau ekor kurva lebih panjang ke kanan.

Untuk mengetahui tinggi rendahnya hasil belajar IPS siswa, skor rata-rata hasil belajar dikonversikan dengan menggunakan kriteria rata-rata ideal $\left(\mathrm{M}_{\mathrm{i}}\right)$ dan standar deviasi ideal $\left(\mathrm{SD}_{\mathrm{i}}\right)$ pada skala lima. Berdasrakan hasil konversi, diketahui skor rata-rata hasil belajar IPS siswa kelompok kontrol adalah 18,92 berada pada kategori tinggi.

Sebelum melakukan analisis data untuk uji hipotesis, terlebih dahulu dilakukan uji normalitas dan uji homogenitas varians. Hasil perhitungan uji normalitas pada kelompok eksperimen, diperoleh $\chi_{\text {hitung }}^{2}$ adalah 2,941 dan $\chi_{\text {tabel }}^{2}$ pada taraf signifikansi $5 \%$ dan $\mathrm{dk}=3$

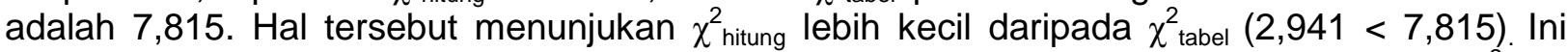
berarti data hasil belajar IPS kelompok eksperimen berdistribusi normal. Sedangkan $\chi^{2}$ hitung pada kelompok kontrol sebesar 2,092 dan $\chi^{2}$ tabel sebesar 7,815 pada taraf signifikansi $5 \%$ dan $\mathrm{dk}=3$. Hal tersebut menunjukkan bahwa $\chi^{2}$ hitung lebih kecil daripada $\chi_{\text {tabel }}^{2}(2,092<7,815)$. Ini berarti data hasil belajar IPS kelompok kontrol berdistribusi normal. Hasil perhitungan uji homogenitas varians, diperoleh $\mathrm{F}_{\text {hitung }}$ sebesar 1,351 , sedangkan $\mathrm{F}_{\text {tabel }}$ dengan $\mathrm{db}$ pembilang $=$ 25 dan $\mathrm{db}$ penyebut $=24$ pada taraf signifikansi $5 \%$ sebesar 1,964 . Dengan demikian, $F_{\text {hitung }}$ lebih kecil daripada $F_{\text {tabel }}(1,351<1,964)$. Sehingga, data hasil belajar IPS kedua kelompok memiliki varians yang homogen.

Setelah diketahui data hasil belajar IPS kelompok eksperimen dan kelompok kontrol berdistribusi normal dan homogen, dilanjutkan dengan melakukan uji hipotesis. Uji hipotesis menggunakan uji-t dengan rumus polled varians $\left(\mathrm{n}_{1} \neq \mathrm{n}_{2}\right)$. Kriteria pengujian, $\mathrm{H}_{0}$ diterima jika $t_{\text {hitung }}<t_{\text {tabel }}$ dan $\mathrm{H}_{0}$ ditolak jika $t_{\text {hitung }}>t_{\text {tabel }}$ dengan taraf signifikansi $5 \%$ dengan $\mathrm{db}=\mathrm{n} 1+\mathrm{n} 2-2$. Berikut ini rangkuman hasil analisis uji-t disajikan pada Tabel 3. 
Tabel 3. Rangkuman Hasil Uji-t

\begin{tabular}{clcccccc}
\hline Data & Kelompok & $\mathbf{N}$ & $\bar{X}$ & $\mathbf{s}^{2}$ & $\mathbf{t}_{\text {hitung }}$ & $\mathbf{d k}$ & $\begin{array}{c}\mathbf{t}_{\text {tabel }} \\
\mathbf{( 5 \% )}\end{array}$ \\
\hline Hasil & Eksperimen & 25 & 22,64 & 11,09 & 3,683 & 49 & 1,667 \\
belajar IPS & Kontrol & 26 & 18,92 & 14,98 & & \\
\hline
\end{tabular}

Keterangan:

$$
\begin{aligned}
\mathrm{N} & =\text { banyak data } \\
\overline{\mathrm{X}} & =\text { rata-rata } \\
\mathrm{s}^{2} & =\text { varians }
\end{aligned}
$$

Berdasarkan Tabel 3, diketahui $t_{\text {hitung }}$ lebih besar daripada $t_{\text {tabel, }}$ maka $\mathrm{H}_{0}$ ditolak dan $\mathrm{H}_{1}$ diterima. Ini berarti terdapat pengaruh yang signifikan model pembelajaran Word Square berbantuan media gambar terhadap hasil belajar IPS siswa kelas V di Gugus II Kecamatan Kubutambahan Tahun Pelajaran 2017/2018.

Perbedaan pembelajaran antara kelompok eksperimen dan kelompok kontrol, tentunya berdampak pada hasil belajar yang diperoleh siswa. Berdasarkan hasil uji hipotesis diketahui bahwa $t_{\text {hitung }}$ lebih besar daripada $\mathrm{t}_{\text {tabel }}(3,683>1,667)$, maka $\mathrm{H}_{1}$ diterima. Ini berarti terdapat pengaruh yang signifikan model pembelajaran Word Square berbantuan media gambar terhadap hasil belajar IPS siswa kelas V di Gugus II Kecamatan Kubutambahan Tahun Pelajaran 2017/2018.

Besarnya pengaruh antara kelompok eskperimen yang diberikan perlakuan dengan menggunakan model pembelajaran Word Square berbantuan media gambar dan kelompok kontrol yang tidak diberikan perlakuan dengan menggunakan model pembelajaran Word Square berbantuan media gambar dapat dilihat dari hasil analisis statistik deskriptif. Skor ratarata kelompok eksperimen adalah 22,64 berada pada kategori sangat tinggi, sedangkan skor rata-rata kelompok kontrol adalah 18,92 berada pada kategori tinggi.

Ada beberapa hal yang menyebabkan terdapat pengaruh yang signifikan model pembelajaran Word Square berbantuan media gambar terhadap hasil belajar siswa. Pertama, model pembelajaran Word Square berbantuan media gambar merupakan cara pembelajaran yang lebih menekankan pada aktivitas siswa daripada guru. Pembelajaran melibatkan siswa dari awal sampai akhir pembelajaran, mulai dari pendahuluan, menyampaikan materi, mengerjakan LKS, menyampaikan hasil hingga menutup pembelajaran. Jadi, pembelajarannya berpusat pada siswa (student center). Pada proses pembelajaran guru sebagai fasilitator. Temuan ini sejalan dengan hasil penelitian Aningsih (2013) pada pembelajaran IPA dengan model pembelajaran Word Square berbantuan media gambar seluruh rangkaian kegiatan yang berlangsung sampai siswa bisa menyimpulkan sepenuhnya dilakukan oleh siswa dengan arahan dari guru. Temuan ini juga sejalan dengan hasil penelitian Ningsih (2017:7) "ditinjau dari proses pembelajaran, aktivitas siswa yang dibelajarkan dengan model pembelajaran kooperatif tipe Word Square lebih aktif dalam pembelajaran. Kegiatan pembelajaran berpusat kepada siswa dan guru sebagai fasilitator".

Kedua, pembelajaran dengan media gambar sebagai media pembelajaran menarik minat belajar dan meningkatkan keaktifan siswa dalam proses pembelajaran. Siswa aktif menjelaskan materi sesuai media gambar. Temuan ini sejalan dengan teori yang mengatakan bahwa penggunaan media pembelajaran dapat membangkitkan minat belajar dan motivasi siswa untuk lebih rajin belajar serta sangat membantu keaktifan siswa dalam proses pembelajaran dan kemudahan bagi guru dalam menyampaikan materi (Wati, 2016). Lebih lanjut Menurut Sudjana dan Rivai (dalam Arsyad, 2005) manfaat penggunaan media pembelajaran dalam proses pembelajaran lebih menarik perhatian siswa dan menumbuhkan motivasi belajarnya.

Ketiga, pembelajaran dengan menggunakan model pembelajaran Word Square berbantuan media gambar dilengkapi dengan LKS Word Square. Pada tahap siswa disuruh 
menjawab soal, siswa menyelesaikan pertanyaan yang ada di LKS tersebut melalui diskusi dengan setiap anggota kelompok melalui bertukar pendapat. LKS Word Square ini membuat siswa terus teliti dalam mengerjakan soal, sehingga berpengaruh terhadap hasil belajar siswa yang lebih baik. Hal ini sejalan dengan teori yang mengatakan bahwa salah satu kelebihan yang dimiliki model pembelajaran Word Square adalah sebagai latihan untuk bersikap teliti dan kritis (Kurniasih dan Berlin, 2015). Lebih lanjut hasil penelitian Aningsih (2013) yang menyatakan bahwa siswa lebih teliti dan tepat dalam menjawab setiap permasalahan yang mereka miliki, sehingga memberikan pengaruh positif terhadap hasil belajar IPAnya. Temuan ini juga sejalan dengan hasil penelitian Mursini (2017) pembelajaran dengan menerapkan model Word Square, menuntut siswa untuk berpikir aktif, disiplin, dan jeli dengan mencari jawaban pada kotak-kotak yang berisi kumpulan huruf abjad.

Keempat, pembelajaran ini menciptakan suasana pembelajaran yang menyenangkan karena model pembelajaran Word Square seperti permainan merangkai huruf pada kotak Word Square. Temuan ini sejala dengan hasil penelitian Muriana (2014) model ini berpengaruh baik dalam meningkatkan hasil belajar karena pembelajaran dengan model Word Square menyenangkan berupa permainan dan siswa lebih banyak terlibat dalam proses pembelajaran. Perdani (2016:8) juga berpendapat "keterlibatan guru dengan siswa dalam kegiatan pembelajaran seperti permainan merangkai huruf acak pada kotak-kota huruf, dapat membuat suasana belajar di kelas menjadi lebih hidup dan menyenangkan".

Kelima, pemberian penghargaan. Pemberian poin dan penghargaan membuat siswa lebih termotivasi untuk mengikuti proses pembelajaran. Oleh karena itu, pemberian penghargaan dan meningkatnya motivasi siswa sangat membantu dalam meningkatkan hasil belajar siswa. Temuan ini senada dengan pendapat Sardiman (dalam Suwatra, 2015) pemberian angka dan hadiah kepada siswa pada proses pembelajaran merupakan langkah yang dapat dilakukan guru untuk menumbuhkan motivasi siswa dalam kegiatan pembelajaran di sekolah. Suwatra (2015:107) juga menyatakan "motivasi menentukan tingkat keberhasilan atau gagalnya perbuatan belajar siswa".

Berbeda dengan pembelajaran pada kelompok kontrol yang tidak diberikan perlakuan dengan menggunakan model pembelajaran Word Square berbantuan media gambar. Pembelajaran dimulai dari penyampaian materi, pemberian tugas, membahas soal, dan terakhir pemberian kuis. Pada pembelajaran seperti itu, guru lebih banyak menjelaskan materi dengan metode ceramah walaupun kadang diselingi dengan tanya jawab. Jadi, pembelajaran menitik beratkan guru sebagai pelaku utama pada proses pembelajaran. Sedangkan siswa hanya mendengarkan guru, sehingga menyebabkan siswa kurang memahami materi. Hal ini sejalan dengan pendapat Anggarini (2013) guru lebih banyak menggunakan metode ceramah dibandingkan mengusahakan siswa untuk dapat menggali pengetahuannya sendiri, sehingga siswa cenderung pasif dan kegiatan pembelajaran berjalan monton. Pembelajaran menitikberatkan proses transfer pengetahuan dan bukan konstruksi pengetahuan. Hal tersebut menyebabkan hasil belajar IPS siswa kelompok kontrol lebih rendah dibandingkan dengan kelompok eksperimen.

Oleh karena itu, terbukti bahwa terdapat pengaruh yang signifikan model pembelajaran Word Square berbantuan media gambar terhadap hasil belajar IPS siswa kelas V di Gugus II Kecamatan Kubutambahan Tahun Pelajaran 2017/2018.

\section{Simpulan dan Saran}

Berdasarkan hasil analisis data, maka dapat disimpulkan bahwa skor rata-rata kelompok eksperimen sebesar 22,64, median sebesar 23, modus sebesar 23,24, standar deviasi sebesar 3,33 , dan varians sebesar 11,09. Data hasil belajar kelompok eksperimen membentuk kurva juling negatif dan skor rata-ratanya berada pada kategori sangat tinggi. Skor rata-rata kelompok kontrol sebesar 18,92, median sebesar 18,51, modus sebesar 17,82, standar deviasi sebesar 3,87 , dan varians sebesar 14,98. Data hasil belajar kelompok kontrol membentuk kurva juling positif dan skor rata-ratanya berada pada kategori tinggi. Hasil perhitungan uji-t untuk uji 
hipotesis, diperoleh $t_{\text {hitung }}$ sebesar 3,683 , sedangkan $t_{\text {tabel }}$ adalah 1,667 . Ini berarti bahwa, $t_{\text {hitung }}$ lebih besar daripada $t_{\text {tabel }}(3,683>1,667)$, maka $\mathrm{H}_{0}$ ditolak dan $\mathrm{H}_{1}$ diterima. Dengan demikian, dapat disimpulkan bahwa terdapat pengaruh yang signifikan model pembelajaran Word Square berbantuan media gambar terhadap hasil belajar IPS siswa kelas V di Gugus II Kecamatan Kubutambahan Tahun Pelajaran 2017/2018.

Adapun saran yang dapat disampaikan setelah melaksanakan dan memperoleh hasil dari penelitian sebagai berikut. Pertama, kepada guru, disarankan agar lebih kreatif dalam merancang pembelajaran yang bervariasi dengan model pembelajaran inovatif. Pembelajaran juga diusahkan dibantu dengan penggunaan media gambar mengingat siswa SD yang masih berada pada tahap operasional konkret. Kedua, kepada siswa, disarankan lebih berani untuk tampil di depan kelas dalam menyampaikan pendapat dan jangan pernah takut untuk salah. Selain itu, tetap serius dan aktif dalam mengikuti proses pembelajaran. Ketiga, kepada kepala sekolah, disarankan agar hasil penelitian ini dapat dijadikan dasar pertimbangan dalam mengambil kebijakan yang paling tepat dalam membina guru-guru untuk meningkatkan kemampuan mengelola proses pembelajaran di sekolah. Keempat, kepada peneliti lain, disarankan agar melakuan penelitian pada sampel yang lebih besar dan materi yang berbeda.

\section{Daftar Rujukan}

Agung, Anak Agung Gede. 2014. Buku Ajar Metodologi Penelitian Pendidikan. Malang: Aditya Media Publishing.

Anggarini, I. G. A. Mas Dewi. 2013. "Pengaruh Model Pembelajaran Kooperatif Talking Stick Berbasis Aneka Sumber terhadap Hasil Belajar IPS Siswa Kelas V SD Negeri 5 Dalung”. Mimbar PGSD, Vol. 1 No. 1 . Tersedia pada http://ejournal. undiksha.ac.id/index.php/JJPGSD/article/view/1440 (diakses hari Selasa, 15 Mei 2018).

Aningsih, Ni Ngh. 2013. "Pengaruh Model Pembelajaran Word Square Berbantuan Media Gambar terhadap Hasil Belajar IPA Kelas IV SD Gugus 1 Kecamatan Pupuan”. Mimbar PGSD, Vol. 1 , No. $1 . \quad$ Tersedia pada https://ejournal.undiksha.ac.id/index.php/JJPGSD/article/view/1260/1123 (diakses hari Rabu, 20 Desember 2017).

Aqib, Zainal. 2016. Model-Model, dan Strategi Pembelajaran Kontekstual (Inovatif). Bandung: Yrama Widya.

Arsyad, Azhar. 2005. Media Pembelajaran. Jakarta: PT Raja Grafindo Persada.

Kurniasih, Imas dan Berlin Sani. 2015. Ragam Pengembangan Model Pembelajaran untuk Peningkatan Profesionalitas Guru. Jakarta: Kata Pena.

Lestari, Kd. Tia. 2013. "Pengaruh Model Pembelajaran Word Square terhadap Hasil Belajar IPS Kelas III SD. Mimbar PGSD, Vol 1, No. 1. Tersedia pada https://ejournal.undiksha.ac.id/index. php/JJPGSD/article/view/752/625 (diakses hari Rabu, 20 Desember 2017).

Muriana, Dwa Gd Alit. 2014. "Pengaruh Model Pembelajaran Word Square terhadap Hasil Belajar IPA Siswa Kelas IV SD Desa Tista Tahun Pelajaran 2013/2014". Mimbar PGSD, Vol. 2 , No. $1 . \quad 10$ Tersedia pada https://ejournal.undiksha.ac.id/index.php/JJPGSD/article/view/2485/2145 (diakses hari Rabu, 20 Desember 2017).

Mursini, Tri. 2017. "Pengaruh Model Word Square terhadap Hasil Belajar IPS Kelas IV SD Negeri 36 Pontianak Kota”. Jurnal Pendidikan dan Pembelajaran, Vol. 7, No. 1. Tersedia 
pada http://jurnal.untan.ac.id/index. php/jpdpb/article/view/23649/18560 (diakses hari Jumat, 19 Januari 2018).

Ningsih, I Made rWahyu Sasmita. 2017. "Pengaruh Model Pembelajaran Kooperatif Tipe Word Square terhadap Hasil Belajar Bahasa Indonesia”. Mimbar PGSD, Vol. 5, No, 2. Tersedia pada https://ejournal. undiksha.ac.id/index.php/JJPGSD/article/view/10993/7044 (diakses hari Selasa, 15 Mei 2018).

Perdani, I Gusti Ayu Mirah. 2016. "Pengaruh Model Pembelajaran Word Square terhadap Hasil Belajar IPA Pada Siswa Bermotivasi Belajar Berbeda di Kelas IV SD". Mimbar PGSD, Vol.4, No, $1 . \quad$ Tersedia pada https://ejournal.undiksha.ac.id/index.php/JJPGSD/article/view/7695 (diakses hari Selasa, 15 Mei 2018).

Permendikbud Nomor 103 Tahun 2014 tentang Pembelajaran pada Pendidikan Dasar dan Pendidikan Menengah.

Rusman, 2015. Pembelajaran Tematik Terpadu Teori, Praktik dan Penilaian. Jakarta: PT Raja Grafindo.

Sadiman, dkk. 2005. Media Pendidikan. Jakarta: PT Raja Grafindo Persada.

Susanto, Ahmad. 2016. Teori Belajar dan Pembelajaran di Sekolah Dasar. Jakarta: Kencana.

Suwatra, dkk. 2015. Belajar dan Pembelajaran Sekolah Dasar. Singaraja: Jurusan Pendidikan Guru Sekolah Dasar, Fakultas IImu Pendidikan, Universitas Pendidikan Ganesha.

Trianto. 2014. Model Pembelajaran Terpadu. Jakarta: Bumi Aksara.

Wati, Ega Rima. 2016. Ragam Media Pembelajaran. Jakarta: Kata Pena 